УДК (629.424.24 - 629.424.27)

\title{
СКЛАДЕНІСТЬ ДИЗЕЛЬ-ПОЇЗДІВ ПРИМІСЬКОГО СПОЛУЧЕННЯ
}

\author{
С. Г. Жалкін, канд. техн. наук, проф., О. Д. Жалкін, магістр \\ СОСТАВНОСТЬ ДИЗЕЛЬ-ПОЕЗДОВ ПРИГОРОДНОГО СООБЩЕНИЯ
}

С. Г. Жалкин, канд. техн. наук, проф., А. Д. Жалкин, магистр

\section{THE NUMBER OF DIESEL-TRAIN CARS THAT USED IN SUBURBAN TRAFFIC}

\section{S. G. Zhalkin, Ph.D., prof., O. D. Zhalkin, master's degree}

На неелектрифікованих дільниияя залізницьь Украӥни експлуатуються дизель-поӥзди Угорського виробництва, Ризького вагонобудівного заводу (Латвія), ХК «Лугансктепловоз». 3 метою порівняння ефективності їх застосування виконано аналіз показників роботи дизель-поїдів з різною передачею потужності, різними силовими установками, різної складеності поїзів. Кращі показники у приміському та місиевому сполученні мають дизельпоӥзди з гідропередачею потужності зі складеністю за формулою $M+4 \Pi+M$.

Ключові слова: дизель-поӥзд, гідропередача, складеність, дизель, паливо, ивидкість, прискорення, пасажирообіг, пасажиромісткість, прискорення, колія.

На неэлектрифицированных участках железных дорог Украины эксплуатируются дизель-поезда Венгерского производства, Рижского вагоностроительного завода (Латвия), ХК «Лугансктепловоз». С ичелью сравнения эффективности их применения выполнен анализ показателей работы дизель-поездов с разной передачей мощзнсти, различными силовыми установками, различной составности поездов. Лучшие показатели в пригородном $u$ местном сообщении имеют дизель-поезда с гидропередачей мощности составностью по формуле $M+4 \Pi+M$.

Ключевые слова: дизель-поезд, гидропередача, составность, дизель, топливо, скорость, пассажирооборот, пассажировместимость, ускорение, путь.

In article information about diesel-trains. On non-electrified sections of Ukrainian railways are operated such series of diesel trains:

- D1 formula of train $(M$ (motor wagon $)+2 T$ (trailer wagon $)+M)$ that has been built in Hungary with hydro-mechanical transmission;

- DRIA formula of train $(M+4 T+M)$ that has been built in Latvia with hydraulic transmission;

- DPL1 formula of train (DL (diesel locomotive) $+3 T+T c c$ (trailer wagon with control cabin) that has been built in Ukraine with a freight locomotive;

- DPL2 formula of train $(D L+4 T)$ also with a freight locomotive;

- DELO1, DELO2 (2M+1 or 2 T) that has been built in Ukraine with electrical transmission).

With aim to determine the effectiveness, in article was made the analysis of indicators of diesel-trains work with different transmissions and different formulas. Analysis showed, that the best indicators of diesel trains work has diesel-trains with hydraulic transmission with formula $(M$ $+4 T+M)$ with ability to change number of trailer wagons to $(M+2 T+M)$ or $(M+T+M)$. 
Although diesel-trains should has the ability to work in pairs with such formulas $(M+T+M)+(M$ $+T+M)$ or $(M+2 T+M)+(M+2 T+M)$ depending to the conditions of using.

Keywords: diesel-train, hydraulic transmission, number of cars, diesel, fuel, speed, acceleration, passenger traffic, passenger capacity, acceleration, path.

\section{Вступ.}

Провідну роль у забезпеченні потреб виробничої сфери і населення України в перевезеннях відіграє залізничний транспорт. На сьогодні його частка у вантажообігу країни становить понад $80 \%$ (без урахування трубопровідного транспорту) та пасажирообігу близько 50\%, який здійснюється всіма видами транспорту. Традиційними перевагами залізничного транспорту $є$ його економічність , безпечність, доступність та екологічність.

Пасажирські перевезення, у тому числі у приміському сполучені, завжди були збитковими та дотувалися за рахунок вантажних перевезень. Це викликано специфікою таких перевезень, до якої відносяться простої локомотивного та моторвагонного рухомого складу (МВРС) в пунктах оберту у очікуванні зворотнього рейсу, сезонні коливання пасажиропотоку, зношеність рухомого складу та експлуатація зверх нормативного терміну, не повна компенсація за перевезення пільгових категорій громадян, та інше. Тому підвищення економічної ефективності пасажирських перевезень $\epsilon$ актуальною задачею.

Постановка проблеми у загальному вигляді та іï зв'язок із важливими науковими та практичними завданнями.

Програмою реформування залізничного транспорту України передбачено відокремлення пасажирських перевезень - в першу чергу приміських та місцевих - від вантажних перевезень 3 подальшою передачею цих перевезень приватним компаніям, [1]. У теперішні часи створено Головне управління приміських перевезень, а в складі залізниць служби приміських перевезень. Для усунення збитковості потрібно розробити вимоги до нового МВРС в частині застосування сучасних економічних силових установок, розробки нового рухомого складу з гнучкою системою переформування кількості вагонів в залежності від розміру пасажиропотоку, що ліквідує порожні пробіги дизель-поїздів, визначитися 3 типом передачі потужності, створення гібридних силових установок та інше, [2,3].

\section{Аналіз останніх досліджень і публікацій.}

Дизель-поїзди набули широкого застосування в обслуговуванні пасажирських перевезень на залізницях багатьох країн світу. У більшій мірі вони використовуються в приміському (на відстані до 150 км) або місцевому сполученні (відстань від 150 до 700 км) на неелектрифікованих залізничних ділянках, [2,4]. Можливість їхнього використання, як на другорядних лініях 3 невеликим пасажиропотоком, так i на головних напрямках 3 інтенсивними перевезеннями пасажирів на більш далекі відстані привела до того, що по конструктивному виконанню й експлуатаційним характеристикам дизельпоїзди відрізняються великою різноманітністю. Поряд 3 дизель-поїздами невеликої потужності 3 одним або двома причіпними вагонами позитивно зарекомендували себе в міжнародних транс'європейських пасажирських перевезеннях багатовагонні дизель-поїзди iз силовими установками, сумарна потужність яких досягає 1500 кВт, [5].

В якості силових установок в дизельпоїздах, як правило, використовуються чотиритактні швидкохідні дизелі, які можуть розташовуватися в кузові, під вагоном і на візку. В якості передач потужності на дизель-поїздах використовуються всі відомі різновиди передач. Найбільш широко використовується на дизель-поїздах гідравлічна передача. Однак гідропередачі уступають електричним передачам 3 асинхронним приводом по ряду показників. У зв'язку із цим останнім часом частина виробників при конструюванні дизельпоїздів віддають перевагу електропередачам. Набирає розвиток тенденція створення дизель-поїздів 3 комбінованим тяговим приводом (гібридним). Наприклад, 
поїзд Lirex оснащений двома гіроскопічними акумуляторами енергії, що заряджаються за рахунок енергії гальмування. Накопичену енергію можна використати при пуску й розгоні поїзда, а також для живлення різного бортового устаткування. Залежно від очікуваного пасажиропотоку поїзд може бути 3 вагонним, 6, 9 або 12 вагонним при зчіплюванні модулів, [6]. В літературі відсутні дані по економічній ефективності роботи дизель-поїздів різної складеності, 3 різними типами передачі потужності, різними силовими установками, а виробники дизель-поїздів публікують інформацію тільки про технічні показники, які передбачені конструкцією.

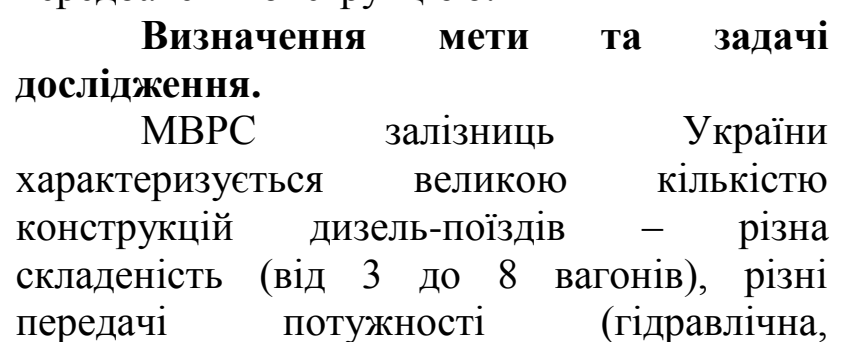
електрична, локомотивна тяга), різні двигуни різної потужності, різна конструкція вагонів та візків та інше. Такий стан значно збільшує витрати на ремонт, виготовлення запасних частин, виготовлення технологічного обладнання для ремонту, підготовку ремонтного й експлуатаційного персоналу, $[2,7]$.

Метою цього дослідження є розробка пропозицій по зменшенню витрат в експлуатації, удосконаленню конструкції нових дизель-поїздів, модернізації діючих.

Задачею дослідження є збір та аналіз показників експлуатації, обгрунтування пропонуємих пропозицій по підвищенню ефективності роботи дизель-поїздів.

\section{Основна частина дослідження.}

Особливостями приміських перевезень, що впливають на організацію руху приміських поїздів, є:

- концентрація перевезень у великих центрах (містах);

- масовість перевезень зі значною кількістю поїздок на одного пасажира на рік;

- перевезення здійснюються на короткі відстані;

- різке падіння пасажиропотоку на дільниці при віддаленні від головної станції;
- нерівномірність перевезень по сезонах року, дням тижня та по годинам доби, наявність міжсезонної кореспонденції пасажиропотоків.

Графік руху приміських поїздів на залізниці розробляється 3 урахуванням зручного за часом підвозу робітників на підприємства до початку роботи та своєчасного вивозу їх до місця проживання після закінчення роботи, а також задоволення потреби населення у під'їзді до поїздів місцевого та дальнього сполучення в пунктах пересадки. Доцільність курсування приміських поїздів визначається від наявності пасажиропотоку, фактичних надходжень від продажу проїзних документів i компенсацій від місцевих органів виконавчої влади за перевезення пільгових категорій громадян, [12].

На неелектрифікованих дільницях залізниць України, протяжність яких майже 12 тис. км, експлуатуються дизель-поїзди Д1 Угорського виробництва, Ризького вагонобудівного заводу (Латвія) ДР1А (44,5\% та 39,1 \% від загальної кількості відповідно) 3 гідравлічною передачею потужності та виробництва ХК «Луганськтепловоз» (біля 16\%) ДТЛ1, ДТЛ2, ДПЛ1 i ДПЛ2 з локомотивною тягою (вантажні тепловози 2ТЕ116, 2M62, М62). Результати розрахунків та експлуатація таких дизель-поїздів показали, що використання магістральних тепловозів 3 їх характеристиками та масою для потягів приміського сполучення недоцільне, [2,7].

Для приміського сполучення були виготовлені дизель-поїзди ДЕЛ01 3 застосуванням дизель-агрегата 588ДА вітчизняного виробництва (завод ім. Малишева, м. Харків) та ДЕЛ02 з силовим модулем 12V183ДЕ фірми МTU (Німеччина). Обидва дизель-поїзди мають електричну передачу потужності зміннопостійно-змінного струму 3 асинхронними тяговими двигунами, конструкційну швидкість 130 км/год., прискорення 0,4 м/сек ${ }^{2}$. Застосовані уніфіковані вагони приміського сполучення серії 1003 в габариті Т у тридверному виконанні кузова вагонів, $[2,8]$.

$\begin{array}{crrr}\text { У } & \text { приміському } & \text { та } & \text { місцевому } \\ \text { сполученні } & \text { застосовуються } & \text { також }\end{array}$ 
пасажирські тепловози пристосовані для пасажирських перевезень маневрові тепловози ЧМЕ3, вантажні М62, електровози ВЛ80 з причіпними вагонами загального або плацкартного типу. Економічна ефективність таких поїздів украй низька. Досвід експлуатації показує, що чотирьохвагонний дизель-поїзд, наприклад, i3 двох автомотрис АЧ2 й двох причіпних вагонів, у порівнянні 3 поїздом із чотирьох вагонів й односекційного тепловоза, витрачає палива на 1 пасажиро-кілометр у 1,9-2 рази менше. Експлуатується невелика кількість рейкових автобусів 620M, 630M виробництва фірми «PESA Bydgoszcz» (Польща) та РA2 Митіщинського заводу «Метровагонмаш» (РФ).

Виконаний аналіз застосування дизель-поїздів у країнах світу та різних виробників показав, що на даний момент простежується тенденція прискореного переходу перевезень у приміських сполученнях 3 локомотивної тяги на більш легкий i економічний моторвагонний рухомий склад (електро- та дизель-поїзди). Відстань між зупинками у приміському сполученні складає у різних країнах від 3 до 40 км, відрізняються також тягові плечі - від 19 км до 300 км, [2].

Гідропередачі - компактні, надійні, довговічні, прості в експлуатації, [9,10]. Однак переваги гідравлічної передачі які наведені у літературі, у порівнянні 3 електричною, належать до того періоду, коли застосовувалися колісно-моторні тягові двигуни, що мають відомі недоліки в порівнянні 3 асинхронними двигунами $[8,11]$. Щоб дати об'єктивну оцінку переваг i недоліків той чи іншої передачі потужності треба виконувати аналіз характеристик цих передач, вартість їх виготовлення та витрати на утримання, вплив на колію, одержання максимального прискорення при розгоні, термін окупності та інше. У більшості країн світу спостерігається чітка картина 3 використання передач: механічні при потужності менш 220 кВт, гідравлічні звичайно при потужностях до 750 кВт, електричні передачі при великих потужностях.

Для аналізу параметрів дизель-поїзда та оцінки його технічного рівня застосовують такі техніко-економічні показники: питома витрата палива, ресурс та потужність силової установки (дизеля), вага (навантаження на вісь), сила тяги тривалого режиму, конструкційна швидкість, прискорення на початку руху та уповільнення при гальмуванні, кількість пасажирів та кількість місць для сидіння, загальна кількість місць (коефіцієнт місткості), кількість пасажирів, яка приходиться на одні вхідні двері, склад дизель-поїзда. Вибір показників можливо здійснювати за методиками які базуються на теорії множин (на теорії бінарних відношень), [12]. Згідно 3 цією теорією дизель-поїзди (ДП) можливо охарактеризувати номенклатурою показників

$$
X=\left\{\mathrm{x}_{1}, \mathrm{x}_{2}, \mathrm{x}_{3}, \ldots \mathrm{x}_{n}\right\}
$$

де $\mathrm{X}$ - номенклатура параметрів ДП; $\mathrm{x}_{1}, \mathrm{x}_{2}, \mathrm{x}_{3} \ldots \mathrm{x}_{\mathrm{n}}-\mathrm{n}-и$ й параметр ДП.

корисного економічного ефекту від використання ДП,

Вибір номенклатури технічних показників виконується за критерієм

$$
\Delta E_{\Sigma}=\Delta E_{\text {експл.вит }}+\Delta E_{\text {вик.роб }}+\Delta E_{\text {вик.ремонт }}
$$

де $\Delta E_{\Sigma}$ - сумарний економічний ефект від використання ДП;

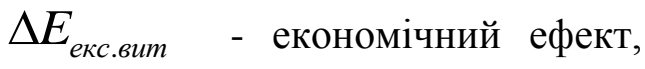
який отримується від зменшення експлуатаційних витрат; 


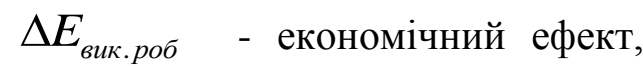
який отримується від збільшення обсягів роботи;

$$
\Delta E_{\text {вит.ремонт }} \text { - економічний }
$$

ефект, який отримується від зменшення витрат на обслуговування та ремонт.

Аналіз ефективності та умов роботи дизель-поїздів виконуємо стосовно таких, які працюють на залізницях України у приміському русі - Д1 та ДР1А 3 гідропередачею, ДПЛ1 3 локомотивною тягою та ДЕЛ02 3 електропередачею змінного струму. Основні параметри дизельпоїздів наведені у таблиці 1.

Таблиця 1 - Основні параметри дизель-поїздів Д1, ДР1А, ДПЛ1, ДЕЛ02.

\begin{tabular}{|c|c|c|c|c|}
\hline \multirow{2}{*}{ Параметри } & \multicolumn{4}{|c|}{ Дизель-поїзди } \\
\hline & Д1 & ДР1А & ДПЛ1 & ДЕЛ02 \\
\hline 1 & 2 & 3 & 4 & 5 \\
\hline $\begin{array}{l}\text { Складеність, вагон } \\
\text { (секція) }\end{array}$ & $\mathrm{M}+2 \Pi+\mathrm{M}$ & $\mathrm{M}+4 \Pi+\mathrm{M}$ & Т+3П+Пку & $\mathrm{M}+\Pi+\mathrm{M}$ \\
\hline Потужність СУ, кВт & $2 \times 536$ & $2 \times 735$ & 1470 & $2 \times 550$ \\
\hline $\begin{array}{l}\text { Конструкційна } \\
\text { швидкість, км/год }\end{array}$ & 120 & 120 & 100 & 130 \\
\hline $\begin{array}{l}\text { Максимальна } \\
\text { швидкість на перегоні, } \\
\text { км/год }\end{array}$ & 82,7 & 86,9 & 87,1 & 82,6 \\
\hline 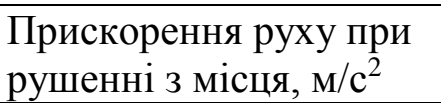 & 0,4 & 0,42 & 0,43 & 0,40 \\
\hline Маса поїзда, т & 237 & 346 & 411 & 232 \\
\hline $\begin{array}{l}\text { Навантаження на вісь, } \\
\text { яка рухає, тс: }\end{array}$ & & & & \\
\hline - моторного вагону; & 17,0 & 18,5 & 19,8 & 20,4 \\
\hline - причіпного вагону. & 8,7 & 9,4 & 11,5 & 11,5 \\
\hline $\begin{array}{l}\text { Кількість місць для } \\
\text { сидіння }\end{array}$ & 400 & 648 & 508 & 340 \\
\hline $\begin{array}{l}\text { Максимальна } \\
\text { пасажиромісткість, осіб }\end{array}$ & 704 & 1143 & 1020 & 890 \\
\hline $\begin{array}{l}\text { Питома маса на одне } \\
\text { місце, кг/місце }\end{array}$ & 512,50 & 416,66 & 584,64 & 511,76 \\
\hline $\begin{array}{l}\text { Кількість пасажирів на } \\
\text { одні вхідні двері, осіб }\end{array}$ & 64 & 64 & 45 & 45 \\
\hline $\begin{array}{l}\text { Питомі витрати } \\
\text { потужності, кBт/т }\end{array}$ & 5,17 & 4,24 & 3,57 & 4,74 \\
\hline Габарит вагонів & $1 \mathrm{~T}$ & $1 \mathrm{~T}$ & $\mathrm{~T}$ & $\mathrm{~T}$ \\
\hline
\end{tabular}

3 таблиці 1 видно, що за складеністю дизель-поїзди залізниць України значно відрізняються - від 3-х вагонів у Д1, ДЕЛ02, чотирьох у ДПЛ1 до шести у ДР1А. Потужність СУ також значно відрізняється: дизель-поїзди Д1 та ДЕЛ02 мають майже однакову потужність, дизель-поїзд ДПЛ1 значно більшу (1470 кВт) в порівнянні 3 іншими. Конструкційна швидкість відрізняється не значно, а максимальна швидкість на перегоні однакова у Д1 та ДЕЛ02 й ДР1А та ДПЛ1 при значній різниці у складеності. Це відноситься також до маси поїзда - найбільш важкий дизель-поїзд ДПЛ1 у 411 тон має максимальну пасажиромісткість у 1020 осіб. Шестивагонний ДР1А має масу 346 тон та максимальну пасажиромісткість у 1143 особи, тобто найбільшу кількість пасажирів на 1 вагон (190 осіб). 
Дизель-поїзди Д1 та ДЕЛ02 при майже однаковій максимальній масі мають різницю пасажиромісткості майже у 190 осіб. Поїзд ДР1А при найбільшій довжині має найменшу масу на одне місце $-416,66$ кг, тобто поїзди 3 гідропередачею мають перевагу по масагабаритним показникам та пасажиромісткості. Питомі витрати потужності дизель-поїздів 3 гідропередачею Д1 та ДР1А (відповідно 4,52 й 4,24 кВт/т) менші в порівнянні з поїздом ДЕЛ02 (4,74 $\kappa В \mathrm{~T} / \mathrm{T} \quad 3$ електропередачею. Уніфіковані вагони приміського сполучення серії 1003 дизель-поїздів ДПЛ1 та ДЕЛ02, що виконані у габариті $\mathrm{T} 3$ тридверним кузовом, дозволяють скоротити час посадки і висадки пасажирів, зменшити кількість пасажирів на одні вихідні двері з 64 до 45 осіб відповідно у дизель-поїздах ДР1А та ДЕЛ02, що підвищує комфортність умов перевезення пасажирів.

Як показує аналіз прискорення у всіх розглянутих у таблиці 1.1 дизель-поїздів прискорення фактично однакове й не залежить від типу передачі потужності.
Навантаження на рейки колії від колісних пар, що рухають на дизель-поїздах 3 гідравлічною передачею потужності значно нижче в порівнянні 3 електричною передачею як 3 асинхронним, так i локомотивним приводом. Таким чином, дизель-поїзди 3 гідравлічною передачею можуть експлуатуватися на колії з легкою верхнею будовою, що характерно для міського та приміського руху дизель-поїздів. Двохвісні візки дизель-поїздів Д1 та ДР1А дозволяють їм вписуватися у криві колії 3 мінімальним радіусом у 100 метрів при швидкості у 5 км/год, у той де час як тривісним візкам дизель-поїздів ДПЛ1 потрібні мінімальні радіуси кривих у $125 \mathrm{M}$.

Питомі витрати палива на тягу дизельпоїздів на різних залізницях значно відрізняються навіть у поїздів однісї серії. Це пов'язано зі станом, в основному силових установок, терміном служби та умовами експлуатації, показниками роботи дизельних двигунів. Середня витрата палива за 2 роки по залізницям наведена у таблиці 2.

Таблиця 2 - Середня витрата палива дизель-поїздами по залізницям України

\begin{tabular}{|l|c|c|c|c|}
\hline \multirow{2}{*}{ Залізниця } & \multicolumn{3}{|c|}{ Питома витрата палива ДП, кг $/ 10^{4}$ ткм брутто } \\
\cline { 2 - 5 } & Д1 & ДР1А & ДПЛ1 & ДЕЛ02 \\
\hline 1 & 2 & 3 & 4 & 5 \\
\hline Південна & - & 83,15 & - & - \\
\hline Львівська & 107,35 & 93,80 & 107,25 & 131,15 \\
\hline
\end{tabular}

Продовження таблиці 2.

\begin{tabular}{|l|c|c|c|c|}
\hline \multicolumn{1}{|c|}{1} & 2 & 3 & 4 & 5 \\
\hline Одеська & 113,25 & - & - & 108,36 \\
\hline Південно - Західна & - & 70,87 & - & - \\
\hline Донецька & 107,87 & - & - & 119,76 \\
\hline $\begin{array}{l}\text { Середня по } \\
\text { Укрзалізниці }\end{array}$ & 109,50 & 82,60 & 107,25 & \\
\hline
\end{tabular}

Якщо витрата палива дизель-поїздами Д1 на Львівській та Одеській залізницях відрізняються в межах 9,4\%, то на новій серії дизель-поїздів типу ДЕЛ02 з передачею змінного струму та асинхронним приводом різниця у витратах палива значна - 131,15 та 108,36 кг $/ 10^{4}$ ткм брутто відповідно. Це можливо частково пояснити різними умовами експлуатації - на Львівській залізниці дизель-поїзди експлуатуються на ділянках колії, що розташовані у горах.
Найменшу питому витрату палива мають дизель-поїзди серії ДР1А (не дивлячись на позанормативний пробіг від побудови), яка на Південно-Західної залізниці складає 70,87 кг/10 4 ткм брутто, а найбільша витрата у ДП серії ДЕЛ02 3 електричною передачею потужності - 131,15 кг $/ 10^{4}$ ткм брутто (різниця у $54 \%$ ). Дизельпоїзди ДПЛ1 з тепловозною тягою (тепловоз М62) мають питому витрату палива однакову в порівнянні 3 поїздами Д1 на 
одній й той же Львівській залізниці. У той же час тепловози М62, які використовуються в міжрегіональному сполученні 3 пасажирськими поїздами на цій же залізниці, мають витрату палива на 9,5 кг/10 4 ткм брутто меншу (або на 9,1\%), що вказує на недоцільність застосування вантажних тепловозів у приміському сполученні. Менші витрати палива дизель-поїздів Д1 та ДР1А пояснюються також тим, що опалення пасажирських салонів виконується теплотою охолоджуючої рідини дизеля та теплоти від гідропередачі (у зимовий період доповнюється казаном).

Огляд нормативних документів, програм, літературних джерел показує, що відсутня програма модернізації дизельпоїздів по заміні неекономічних, застарілих силових установок на сучасні, застосування науково обгрунтованих пропозицій по зменшенню витрат палива у сезонні періоди експлуатації, [13] створення гібридних силових установок $[14,15,16]$.

\section{Висновки 3 дослідження i перспективи, подальший розвиток у даному напрямку.}

1. Дизель-поїзди набули широкого застосування в обслуговуванні пасажирських перевезень на залізницях багатьох країни світу в приміському й місцевому сполученнях на неелектрифікованих залізничних ділянках як на другорядних лініях 3 невеликим пасажиропотоком, так i на головних напрямках (регіональні та міжрегіональні перевезення).

2. Промисловістю України за роки незалежності розроблено і побудовано декілька типів дизель-поїздів різної конструкції. Застосування дизель-поїздів 3 локомотивною тягою показало їх економічну недоцільність у приміських перевезеннях пасажирів.

3. В якості передач потужності на дизель-поїздах використовуються всі відомі різновиди передач потужності. Найбільш широко використовується гідравлічна передача потужності (74\% від загальної чисельності дизель-поїздів України). Але 3 розвитком електропередач змінного струму 3 асинхронним приводом такі передачі по техніко-економічним показникам
4. Аналіз експлуатації дизель-поїздів показав, що кращі показники у приміському, місцевому сполученні мають дизель-поїзди 3 гідропередачею потужності зі складеністю М $+4 \Pi+\mathrm{M}$ з гнучкою схемою зміни кількості причіпних вагонів, наприклад: $\mathrm{M}+2 \Pi+\mathrm{M}$, $\mathrm{M}+\Pi+\mathrm{M}$. Повинна бути передбачена експлуатація зчеплених поїздів (система багатьох одиниць), наприклад: $(\mathrm{M}+\Pi+\mathrm{M})$ $+(\mathrm{M}+\Pi+\mathrm{M}),(\mathrm{M}+2 \Pi+\mathrm{M})+(\mathrm{M}+2 \Pi+\mathrm{M})$ в залежності від потреб оператора перевезень пасажирів.

5. Для підтримки дизель-поїздів у роботоспроможному стані необхідно активізувати капітальні ремонти 3 подовженням терміну експлуатації (КРП) та комплексну модернізацію 3 заміною застарілих та зношених силових установок новими, такими як Power Pack 3 двигунами фірми MTU (Німеччина) та гідропередачею Voith, які експлуатуються у багатьох країнах світу, у тому числі на залізницях України. Але у подальшій перспективі потрібно визначитись 3 типами дизель-поїздів, які можливо виробляти в Україні або придбати за кордоном.

6. 3 метою зменшення витрат палива та оливи при комплексній модернізації необхідно застосовувати наукові досягнення в галузі покращення роботи двигунів дизельпоїздів на холостому ході та неусталених режимах (гібридні СУ), енергозбереження систем дизеля та гідропередачі у періоди сезонної експлуатації, подовження термінів придатності робочих рідин (оливи) дизеля та гідропередачі.

Перспектива подальших досліджень полягає у тому, щоб розробити схему гібридної силової установки дизель-поїзда 3 гідравлічною передачею потужності 3 застосуванням гідроакумулятора, що дасть змогу усунути неусталені процеси, зменшити витрату палива й викиди шкідливих речовин при роботі дизеля на холостому ході, зрушенні з місця та розгоні після стоянки. 


\section{Список використаних джсерел}

1. Державна цільова програма реформування залізничного транспорту на 2010-2019 роки, [Текст] затверджена постановою Кабінету Міністрів України від 16.12.2009 №1390.

2. Басов Г.Г. Прогнозування розвитку дизель-поїздів для залізниць України [Текст] / Г.Г. Басов. - Харків: Алекс+, 2004. -240с.

3. Яновський П.О., Христофор О.В. Перспективні напрями удосконалення системи приміських пасажирських перевезень. [Текст] Журнал «Локомотив-інформ» №11-12, 2009 изд. Рухомий склад С. 12-16, м. Харків ISSN1994-2338.

4. Дизельный моторвагонный подвижной состав для железных дорог Европы [Текст] //Железные дороги мира. - 1999. - №7. - С.21-25.

5. В.И. Карянин. Компания Stadler на Экспо 1520. [Текст] Журнал «Локомотив», №11, 2013г., 38-40c.

6. Дизель-поезд Lirex [Текст] // Железные дороги мира. - 2001. — №2. - C.27-34.

7. Раков В.А. Локомотивы и моторвагонный подвижной состав железных дорог Советского Союза (1976-1985 г.) [Текст] М: Транспорт, 1990. - 238c.

8. Басов Г.Г., Носеєв В.І. Електропередача дизель-поїзда ДЕЛ-01 [Текст] / Вісн. СНУ. Луганськ: - 2000. - №5(27). - С. 64-68.

9. Дизель-поезда: Устройство, ремонт, эксплуатация. [Текст] / Б.М. Лернер, Н.П. Ковалев, В.Л. Лебедев и др. М.: Транспорт, 1982, 279с.

10. Шаройко, П.М. Гидравлические передачи тепловозов: учеб. пособие для вузов ж.д. транспорта [Текст] / П.М. Шаройко, В.Т. Середа. - М.: Транспорт, 1969. - 160 с.

11. Исаев И.П. Асинхронный привод электропоездов. [Текст] Железнодорожный транспорт. - 1987. -№1. - С.43-45.

12. Александров П.С. Введение в общую теорию множеств и функций. [Текст] - М.: Гостехиздат, 1948. - $211 \mathrm{c.}$

13.Пат. №107584 Україна. Стаціонарна установка для прогрівання систем тепловозів та дизель-поїздів [Текст] / Жалкін С.Г., Жалкін Д.С., Жалкін О.Д. / № а201211230, опубл. 26.01.13, Бюл.№2. - 8 с.

14. Бажинов, О.В. Гібридні автомобілі [Текст] / О.В. Бажинов, О.П. Смірнов, С.А. Сєріков, А.В. Гнатов, А.В. Колєсніков. - Харків: Крок, 2008. - 327 с.

15. Пат. на корисну модель №98807. Гібридна силова установка рейкового транспорту [Текст] / Жалкін О.Д., Тартаковський Е.Д., Жалкін С.Г., Жалкін Д.С. та інші / № u201411899, опубл. 12.05.2015, Бюл. №9. - 8c.

16. Звіт про науково-дослідну роботу «Зниження витрат палива та шкідливих викидів енергетичними установками під час експлуатації дизель-поїздів» [Текст] / Жалкін Д.С., Жалкін О.Д., Жалкін С.Г., Фалендиш А.П. та інші / УкрДАЗТ, опубл. 11. 03.2015, № держреєстрації 0114U000086,-98c.

Жалкін Сергій Григорович канд. техн. наук, професор кафедри експлуатаиія та ремонт рухомого складу Українського державного університету залізничного транспорту. Тел. (057) 730-10-16. E-mail: abddd@ mail.ru Zhalkin Sergii Grugorovich Ph.D., professor of cathedra maintenance and repair of rolling stock Ukraine State University of Railway Transport.Tel. (057) 730-10-16.E-mail: abddd@mail.ru

Жалкін Олексій Денисович магістр, асистент кафедри експлуатаиія та ремонт рухомого складу Украӥнського державного університету залізничного транспорту. Тел. (093) 545-53-59. E-mail: amp123@ mail.ru

Zhalkin Oleksii Denusovich master's degree, assistant of cathedra maintenance and repair of rolling stock Ukraine State University of Railway Transport.Tel. (093) 545-53-59. E-mail: amp123@mail.ru

Стаття поступила 21.04.2015 